\title{
Current Research and Classroom Practice: \\ Toward More Inclusive Approaches to Literacy Development in Schools
}

\author{
Susan E. Elliott-Johns \\ Nipissing University Centre for Literacy \\ David Booth \\ Nipissing University Centre for Literacy
}

\begin{abstract}
This paper offers an exploration of current research and related practice in boys' literacy development, interprets key findings in the literature, and further explores some of the complex dilemmas and debates related to the 'gender gap'-i.e., differences between the achievement of boys and girls in this area. In conclusion, the authors suggest that governments, policy-makers, administrators, teachers and parents all need to closely examine and consider available research-based strategies and classroom interventions that can effectively support both boys and girls in their literacy development.
\end{abstract}

Keywords: literacy, gender, teacher education, research, practice

Susan E. Elliott-Johns is an Assistant Professor of Language Arts and Literacy Education, at Nipissing University in North Bay, Ontario and a member of the Nipissing University Centre for Literacy Advisory Board.

E-mail: susanej@nipissingu.ca

David Booth is Chair of the Nipissing University Centre for Literacy and Professor Emeritus in the Department of Curriculum, Teaching and Learning at OISE/UT, Toronto, Ontario.

Brock Education, Volume 19, No. 1, Fall 2009, 


\section{Current Research and Classroom Practice: Toward More Inclusive Approaches to Literacy Development in Schools}

In this paper, a brief summary of current research in boys' literacy development provides the context for an exploration of some complex dilemmas and debates associated with the 'gender gap', for example, the perceived 'gap' between the achievement of boys and girls in literacy. Significant findings, as reflected in the literature, are then directly linked to implications for teachers and teacher educators in contemporary classrooms. Six collaborative research projects and two longitudinal action research inquiries are presented and discussed, further illustrating the role of research on boys' literacy in supporting effective classroom practice. An extensive list of Additional Readings and Resources related to the topic of boys' literacy is also included in Appendix A.

\section{Review of the Literature}

During the past ten years, there has been a great deal of assessment, research, and critical examination of the issue of boys' literacy attainment, in Canada, the United Kingdom, Australia, New Zealand, and the United States. Documentation includes government ministries, universities, researchers, educators and authors specializing in the field of gender and literacy. Schools are implementing different strategies to improve the literacy performance of students, and while scores have improved for both girls and boys, girls continue to outperform boys on standardized assessment procedures: the gender gap remains. The gender gap appears to be stabilizing after widening for a short period, and many boys achieve extremely well in all areas, while some girls underachieve. In many schools, "the core of the issue revolves around a minority of pupils" (Younger \& Warrington, 2005).

National and international results show that male elementary and secondary students do not do as well as girls in reading or writing, appear in special education or drop out statistics more often, and are less likely to become university students. Rutter, Caspi, Ferguson et al. (2004) also found that males were more likely to have a reading disability, and were twice as likely to have a learning disability. Boys are more likely than girls to attend special schools, and boys are four times as likely as girls to be identified as having a behavioural, emotional and social difficulty. Fewer boys are graduating from secondary schools and fewer boys than girls are going to postsecondary education (Allen \& Vaillancourt, 2004).

\section{Exploring Research \& Implications for Classroom Practice}

While there is no simple explanation for the gender gap in literacy (Arnot, Gray, James et al., 1998), the results of formal assessments are most often used as the reason for incorporating "best practices" into classrooms, school, districts, provinces, or national initiatives. Some critics question this approach to the reform agenda, citing a lack of focus on "the root causes of the problem of gender identity and structural inequality” (Martino \& Kehler, 2007; Martino, 2008).

Some researchers also suggest that issues of equal opportunities in England in the last decade have been subverted by a paramount concern to address the boys' 'underachievement' debate, and that within this, the emphasis has been on short-term, essentialist responses which assume an homogeneity of gender constructions and imply the perpetuation of conventional masculine stereotypes (Francis \& Skelton, 2005). Approaches such as these have failed to give 
adequate consideration to alternative conceptions of masculinity and femininity (Epstein et al., 1998; Frank et al., 2003; Martino \& Pallotta-Chiarolli, 2003), or to acknowledge the need for policy directions and practical strategies which emphasize a diversity and multiplicity of gender constructions (Younger et al, 2005).

It is clear that an approach ignoring the differentiation among boys in their literacy successes and failures would offer few possibilities for implementing effective change. In order to further study relevant and significant areas of inquiry into "the literacy gap" between boys and girls (especially for those concerned primarily with the results of test scores), it may be of help to examine the body of research and writing that has accrued in different geographical areas. As pedagogy and policies are developed to support literacy competence for all students, there needs to be continuing research into examining the different explanations for the problems many boys are exhibiting in literacy attainment, including gender identity; social and cultural issues; religion; the changing definition of literacy; school cultures; technology; teaching styles; curriculum documents; the place of standardized evaluations; and pre-service and in-service teacher education. Compelling questions continue to arise concerning how these factors are intricately interwoven with regard to school performance (Brown, 2006; Francis \& Skelton, 2005; Lingard, Martino, Mills \& Bahr, 2002; Martino \& Kehler, 2007). For example, there is legitimate concern, supported by research findings, that the reading achievements of some boys need to be examined. However, if we consider the impact of a range of factors on the literacy performance of boys, then "a more differentiated picture emerges which demands that questions be addressed about which groups of boys and girls are most disadvantaged, how and what forms this disadvantage may take, and why this disadvantage occurs" (Collins et al., 2000).

It is essential that efforts to support and improve boys' levels of achievement in literacy should not, inadvertently or otherwise, disadvantage girls. Hammett and Sanford (2008) emphasize that while their intent is by no means to disparage attempts to address literacy learning initiatives for boys, they see as essential the need for practices that engage all children in learning, "with context-appropriate curricular and pedagogical activities, not "band-aid" innovations that group boys into one homogenous mass."

Grouping and educating boys as if they were a 'homogenous' category does them serious injustice. For example, not all boys are failing standardized tests, doing less well than girls, or "hate" to read. It is therefore important to ask, "Which boys are/are not learning?" in order to avoid a 'one-size fits all' approach to instruction. Spence (2008) reminds us that, "Too often, we deal with generalities without recognizing the diversity in our students" (p. 9). However, the research report Raising Boys' Achievements states that, "there are typical patterns of behaviour to which many boys conform, and that although boys are not an undifferentiated group, there are broad similarities within subgroups which allow valid generalizations to be made, and if similar groups of boys are compared with similar groups of girls, there is evidence of lower levels of attainment by boys" (Younger \& Warrington, 2005a, p. 19).

Kathy Sanford (2002) emphasized the need to consider redefining "what counts?" as classroom literacy teaching and learning. For example, Sanford examined intersections and gaps between school literacies (mostly print-based texts) and out-of-school literacies (often non-print texts, media and technology-based texts), and pointed out intersections that often exist between gender, school literacy, and out-of-school "life" literacy.

Martino and Pallota-Chiarolli (2003) have also suggested that boys may be engaging in literate practices outside school that are not reflected in their poor literacy test results, and that "the boys may be advantaged with electronic forms of literate practice useful in the changing 
post-industrial labour market" (p. 23). Tapscott (2009) furthers the argument in the book Grown Up Digital (p. 106):

Net Geners who have grown up digital have learned how to read images, like pictures, graphs, and icons. They may be more visual than their parents are (Sternberg and Preiss 2005). A study of Net Gen college students showed that they learned much better from visual images than from text-based ones. Students of a Library 1010 class at California State University tended to ignore lengthy step-by-step text instructions for their homework assignments, until the instructors switched their teaching methods to incorporate more images. The results were dramatic: students' scores increased by 11 to 16 percent. (Roos, 2008).

In summary, Smith and Wilhelm (2002) focus attention on the need for educators to consider both achievement and attitude:

With respect to achievement:

- Boys take longer to learn to read than girls do;

- Boys read less than girls;

- Girls tend to comprehend narrative texts and most expository texts significantly better than boys do;

- Boys tend to be better at information retrieval and work-related literacy task than girls are.

With respect to attitude:

- Boys generally provide lower estimations of their reading abilities than girls do

- Boys value reading as an activity less than girls do

- Boys have much less interest in leisure reading and are far more likely to read for utilitarian purposes than girls are.

- Significantly more boys than girls declare themselves 'non-readers'.

- Boys spend less time reading and express less enthusiasm for reading than girls do.

- Boys increasingly consider themselves to be nonreaders" as they get older; very few designate themselves as such early in their schooling, but nearly 50 percent make that designation by high school. (Smith \&Wilhelm, 2002, p. 10-11)

Paradoxically, as teaching strategies improve and distractions decrease, results for both genders increase, with girls benefiting more than boys. Thus the achievement gap may actually increase, making the closing of the gap a difficult and complex goal.

Research on boys' literacy attainment makes clear the need to create inclusive literacy school cultures for all students, i.e., boys and girls. Promoting and supporting inclusive literacy cultures is seen as essential for enhancing 'boy friendly' school environments and, thereby, greater learning for all. But how does research on boys' literacy inform inclusive school literacy practices?

Figure 1 summarizes key ideas from research and suggests Action/Reflection as a starting point to assist in the work of teachers and principals building inclusive literacy cultures in their own classrooms and schools. Six examples of related classroom practice illustrate ways in which schools and researchers are examining issues of gender in education together, and working towards organizational planning that supports all students as literacy learners. Each of these 
examples of classroom practice will be described in more detail organized under the following six headings: 1) Individual Differences; 2) What Counts as Literacy? 3) Re-thinking Goals; 4) Understanding the Gendered Nature of Literacy Behaviour; 5) Avoiding Habitus; and 6) WholeSchool Planning Approaches.

Figure 1: Connecting research to classroom practice

\begin{tabular}{|c|c|c|}
\hline RESEARCH & ACTION/REFLECTION & PRACTICE \\
\hline $\begin{array}{l}\text { 1. Individual differences, } \\
\text { variety and plurality (Booth } \\
\text { \& Green, 2009). }\end{array}$ & $\begin{array}{l}\text { How is "strength in diversity" } \\
\text { reflected in policies and } \\
\text { practices in our classrooms? } \\
\text { our school? }\end{array}$ & $\begin{array}{l}\text { Exploring new text forms: } \\
\text { e.g., a school in Florida } \\
\text { purchased a variety of } \\
\text { contemporary graphic, } \\
\text { magazine-style resources for } \\
\text { grade nine students with } \\
\text { reading difficulties. }\end{array}$ \\
\hline $\begin{array}{l}\text { 2. "What counts" as literacy? } \\
\text { (Rakuc, 2008) }\end{array}$ & $\begin{array}{l}\text { Are changing definitions of } \\
\text { literacy and multiple pathways } \\
\text { to becoming literate part of } \\
\text { program planning at our } \\
\text { school? }\end{array}$ & $\begin{array}{l}\text { Initiating a boys' reading } \\
\text { club: A teacher organized a } \\
\text { volunteer boys' reading club } \\
\text { using Internet based literature } \\
\text { circles. }\end{array}$ \\
\hline $\begin{array}{l}\text { 3. Re-thinking goals } \\
\text { (Crawford, 2009; See also } \\
\text { Smith \& Wilhelm, 2002; } \\
\text { 2006) }\end{array}$ & $\begin{array}{l}\text { How much consideration is } \\
\text { given to the What? and Why? } \\
\text { of teaching (re. curriculum and } \\
\text { program planning), and the } \\
\text { How? (e.g., teaching styles, } \\
\text { inquiry-oriented instruction } \\
\text { around essential questions, and } \\
\text { effective uses of technology } \\
\text { for teaching and learning). }\end{array}$ & $\begin{array}{l}\text { Inquiry as a way of learning: } \\
\text { Embedded computer access } \\
\text { in a grade six classroom } \\
\text { changed the nature of their } \\
\text { inquiry projects on social } \\
\text { issues. }\end{array}$ \\
\hline $\begin{array}{l}\text { 4. Increasing understandings } \\
\text { of the gendered nature of } \\
\text { behaviour (Booth, 2009). }\end{array}$ & $\begin{array}{l}\text { What kinds of characteristics } \\
\text { are explanatory of boys' } \\
\text { engagement with literacy both } \\
\text { in and out of our classrooms? } \\
\text { our school? }\end{array}$ & $\begin{array}{l}\text { The voices of boys: in an } \\
\text { educational film made by } \\
\text { David Booth, twenty-two } \\
\text { boys from one urban school, } \\
\text { representing grade one } \\
\text { through grade six, were } \\
\text { interviewed about their } \\
\text { literacy lives. }\end{array}$ \\
\hline $\begin{array}{l}\text { 5. Avoiding 'habitus' } \\
\text { (Marshall, 2009; See also } \\
\text { Smith \& Wilhelm, 2006). }\end{array}$ & $\begin{array}{l}\text { How is this reality taken up } \\
\text { and woven into the fabric of } \\
\text { the learning environment in } \\
\text { contemporary schools and } \\
\text { classrooms? }\end{array}$ & $\begin{array}{l}\text { Going graphic in reading and } \\
\text { writing: eighteen grade ten } \\
\text { boys, all readers who were } \\
\text { experiencing difficulties in } \\
\text { literacy, were involved in } \\
\text { reading a series of graphic } \\
\text { texts. }\end{array}$ \\
\hline $\begin{array}{l}\text { 6. Whole school planning } \\
\text { approaches for teaching and } \\
\text { learning through a 'gendered } \\
\text { lens' (Booth, 2001; See also } \\
\text { Spence, 2008) }\end{array}$ & $\begin{array}{l}\text { How do we utilize analyses of } \\
\text { performance data? Can we } \\
\text { identify practices fostered } \\
\text { across all curriculum areas? at } \\
\text { all grade levels? across the } \\
\text { broader school community? }\end{array}$ & $\begin{array}{l}\text { Gendered language arts } \\
\text { classes: in a grade seven and } \\
\text { eight class in an alternative } \\
\text { school, the boys and girls } \\
\text { were separated by gender for } \\
\text { language arts instruction. }\end{array}$ \\
\hline
\end{tabular}




\section{Individual Differences, Variety and Plurality: Exploring New Text Forms}

This pilot project involved two classes of 30 students, 16 boys and 14 girls in grade nine, in Tampa, Florida, who demonstrated limited reading proficiency on a battery of state tests. The school literacy team decided to incorporate a new set of class texts, a series of ten different books with a graphic, magazine-style format and contemporary selections, and this represented a very different choice compared to the traditional, long anthologies they had used for the last several decades. Using these books each day, the classes explored the major parts of reading (independently and collectively), vocabulary building (context clues, word attack skills, and other vocabulary strategies), literature circles, writing, and comprehension (using multiple intelligences, written responses, and portfolios). Strategic reading instruction helped students to focus on specific techniques in order to strengthen comprehension.

Interviews were conducted with the school principal, the teacher, and the students. Those interviewed were asked to comment on their views of the content, the graphics and formats of the books, the success of the student activities, and the efficacy of the skill-building components of the program. Results of the interviews revealed that the students and staff found that the selections were engaging, the design of the books invitational, and the activities useful and interesting to the students. The students (both boys and girls) responded enthusiastically to the books and participated in unprecedented ways. The selections and activities reinforced literacy learning and helped students collaborate and engage in higher order thinking. There appeared to be little gendered differences in the appreciation of the books and selections; for example, the favourite book for both boys and girls was Martial Arts.

\section{What Counts as Literacy?: Initiating a Boys' Reading Club: Moving Deeply into Text}

In an all boys' school, the grade 7 and 8 language arts teacher organized a volunteer boys' book club to improve their literacy skills and academic self-esteem. This initiative also included the development of an Internet-based literature circle that allowed participants to write responses to the reading material online.

Based on suggestions from the students, the teacher selected copies of a novel for students to read that allowed for an in-depth analysis of social justice issues, as well as issues of masculinity. During weekly lunchtime meetings, the boys talked about the book in an openended, natural conversational setting before working online to complete digital elements in the literature circle structure. The graphic novel selected, the use of a literature circle format, and the engagement of technology together provided an entry point for many of the participants, (especially reluctant readers, English language learners, and students with behavioral exceptionalities). By allowing students to read material that appealed to them and to share their ideas with one another in small groups and online, those students who struggled with the classroom language arts program were seen to be able to contribute most to the club. The teacher commented:

After we completed reading the novel as a group, the students responded to online questions on a website that incorporated elements of a literature circle. As students posted their responses online, other participants read and commented on their peers' work, asking further questions and building upon an exchange of ideas. Students were also encouraged to make contributions to the site and post responses independently throughout the week. The electronic conversation ensued throughout the term with all of the students sharing their responses to the text. 


\section{Rethinking Goals: Inquiry as a Way of Learning}

A grade six class was involved in independent inquiries concerning relevant social issues. The students were involved in most of the decisions that affected their research, working on social issues that concerned them.

Embedded computer access changed the whole nature of the inquiry projects. In this classroom, the students shared daily access to laptops as part of a two-for-one laptop program. As with many classrooms across Ontario, this group of students was actively engaged in deep inquiry regarding social and global issues; the difference, however, seemed to be in how the students were managing information from their daily Internet access, creating a transformational learning environment. The students chose their own topics; used different research modes and resources; assessed the information they found as critical readers; and prepared and presented their data and findings as professional researchers. The teacher commented:

Internet research provides opportunities for students to critically evaluate the purpose and validity of texts in ways that more likely reflect real-life experiences with information. With computer access, the students are developing creative and unique ideas and solutions - again, exactly the type of thinking needed in today's globalized society. Students were interpreting text and images (video and still) simultaneously.

Students who choose their inquiry, their goal, and, in many cases, their presentation mode are much more likely to engage and learn in an environment that fosters the skills and strategies that they will need to survive in the world beyond the classroom. Similarly, boys who may be reluctant to engage in learning within the classroom are often involved in their own learning on their own time, At home they seek out scenarios that provide them with the information they want or need outside of school - Internet gaming, video games, social networking sites, television, even books - all learning that is available to them when they are not in our classrooms. We noted that many students are able to take a leadership role because of their expertise in using particular text forms.

\section{Understanding the Gendered Nature of Literacy Behaviour: The Voices of Boys}

In a recent educational film, twenty-two boys from one urban school, representing grade one through grade six, were interviewed about their literacy lives. The school is a nurturing and exciting community. For example, the library, the computer room, the art on the walls, and the collegiality of the teachers all reveal that children thrive in this setting. The school culture welcomes the students, and the students and the teachers define the culture.

The literacy coach in the school selected a range of boys with different abilities in order to represent the nature of the student body. The interviewer met the boys one by one and chatted with them about reading, writing, and classroom literacy events. There were no prearranged questions; and the interviewer followed the student leads as topics arose. The issues that emerged from the boys' comments as they talked about their literacy lives offer further insights and information about their attitudes, their choices, and their behaviours. They included:

1. Being read to in class by teachers and at night by parents;

2. Visiting the public library every Saturday with friends, playing on the computers and taking out graphic novels and manga; 
3. Feeling that boys read adventure books while girls read Barbie stories;

4. Working in the computer room making zines about the Maya;

5. Seeing parents reading newspapers in English and in other languages, as well as books students bring home from the school library;

6. Being allowed to play computer games only on weekends;

7. Writing stories as a group and submitting them to a publisher;

8. Writing book reports every week and finding the activity difficult;

9. Reading the twenty books in different genres needed for the Silver Birch contest.

\section{Avoiding 'Habitus': Going Graphic in Reading and Writing}

Eighteen Grade 10 boys, all readers who were experiencing many difficulties due to behavior, absenteeism, or general lack of interest, were involved in reading a series of graphic texts. They began by exploring the various text modes and forms they meet in their lives- newspapers, video games, computer sites, comics, magazines, graphs, charts, billboards, e-mails, textbooks, maps. Engagement was the goal, with graphic novels the key.

The concept of the graphic novel was introduced by the teacher through a PowerPoint presentation on the style, art, terminology, font usage, and sound effects. The teacher then selected the graphic text, The Pride of Baghdad by Brian K. Vaughan, artwork by Niko Henrichon. The novel is a short, concise, true account of a series of events that took place in Baghdad in 2003. The United States bombed Baghdad, destroying the Baghdad zoo, killing hundreds of animals and releasing into the streets the ones that survived. The story is told from the point of view of the pride of lions who, at the beginning of the tale, are longing to be free. After the air raid, they escape and are free to roam the streets of Baghdad.

To introduce this novel, the students researched the Internet where they found various news reports, along with statements from some of the American soldiers who lived in the bombed-out zoo for a short time and who were given the task of rounding up the animals. The boys uncovered on line a court martial concerning questionable behavior from one of the soldiers, Students then read the novel at their own pace. Their reading became a social activity as they read a section and moved around to find someone else reading the same section so they could talk about it and share. Some of the boys attempted drawings while they read. The teacher comments:

The interaction, the responses, and the readings were successful, and the boys talked about a variety of the situations in the book. Once all of this was over, I sat down and asked them the question: "What is freedom?" The boys found this question difficult to answer given their personal experiences in comparison with the novel. We moved to the computer lab and began research. We researched women's rights in Afghanistan, child labor, and child soldiers from many countries. The boys worked in small groups and informally shared their new learning with the others. Their work in this unit changed their literacy identities, and opened new horizons.

\section{Whole School Planning Approaches: Gendered Language Arts Classes}

In a grade 7 and 8 class in an alternative school, the boys and girls were separated for Language Arts instruction. In her work with the boys, the teacher had them writing in a variety of modes, especially poetry and script writing. She felt poetry was an effective means for helping them to 
capture their thoughts and feelings at this stage of adolescence. For example, the emotional swings, the observations of the adult world, the new awareness of strong emotions all seemed to fit inside the shapes of the mentor texts that she modeled and shared with them.

The scripting units resulted in each boy having completed two scripts, one drawn from personal experience, the other a satirical comedy. In the spring, the boys and girls came together, held readings of their plays with members of the class as actors, selected the six plays that should be produced, rehearsed the productions, and shared the work in an evening of plays attended by parents.

At the end of the school year the boys stated they felt their success as writers was aided by the separate literacy classes and that they felt secure as contributors to a class poetry booklet which was distributed at graduation. Every student in the class was represented in the collection with several of their poems.

As demonstrated in all these examples of classroom practice informed by research, school-wide efforts are needed not only to understand the critical nature of first recognizing individual differences, but also actively acknowledging 'strength in diversity' across instructional practices and inclusive school climates.

\section{Action Research: Towards More Inclusive Approaches to Literacy}

Increased awareness of the issues and concerns related to boys' literacy attainment and the need to promote more inclusive approaches to school literacy suggests the question: "How can action research be used to further, inform, and enhance the development of effective practice in our contemporary classrooms?"

In the final section of this paper, some recent collaborative research initiatives are described and suggestions offered as to how action research might further assist teachers by informing and enhancing future classroom practices.

\section{The Importance of Environments Conducive to Literacy Learning}

Effective literacy instruction across the curriculum for all students, both boys and girls, needs to be incorporated into classroom programs by educators who understand the relevance of research based classroom practices. For example, Lehman (2009) emphasizes that teaching and learning with literature discussions, literature circles, responses to literature, reading aloud, and the integration of nonfiction and multicultural literature selections are all part of successful classroom environments that promote proficient literacy skills and positive attitudes to learning. Booth \& Rowsell (2007) emphasized three critical elements be in place to support students' work in classroom environments conducive to literacy learning:

1. Choice and access: Students must have access to texts, in print and on line, that they can and want to read

2. Time: Students require essential time to read, to enjoy reading as well as to practice their developing skills and strategies - both at home and at school.

3. Reading instruction: Teachers need to teach reading. Systematic, direct and focused instruction at all grade levels should include how to choose texts, how to become fluent and expressive readers who understand what they are reading and can talk about it when they do not. With proficient instruction and time to read, all students boys and girls - have opportunities to continue growing and developing as readers (and writers). 


\section{Gendered Responses to Fiction: A Case Study}

A recent case study (Booth, 2009) investigated the gendered responses to fiction of thirty boys and girls in grade six classrooms over a three-month period, and examined attitudes revealed through their oral and written responses to five different novels. The study involved fifteen boys and fifteen girls from three schools in two educational districts who volunteered to read and respond to five novels in literature circle format. Particularly relevant to the topic of teachers successfully implementing research based practices, this project hoped to promote awareness of the gender influences on book selection for teachers and librarians; information about grade six girls' and boys' reading behaviours; and raise awareness of text choices by gender, by perceptions of gender, by popular culture, by book format, and by classroom expectations. The project also hoped to promote understanding of the function of literature circles, book sets, oral and artistic responses, book talks, and Internet information in literacy education.

Analysis of the data gathered from students' oral and written responses highlighted important implications for teachers and teacher educators alike in terms of better understanding relationships between literacy attainment and gender. Four major responses to the novels read were identified: powerful uses of language; students' identification with characters; gender issues; and students' responses to 'big issues'. Girls' contributions outweighed boys by twothirds, along with the ability to use advanced vocabulary, mature sentence structure and strong descriptive language, using details and developing insights into both characters and story lines. A direct implication here would appear to be encouraging teachers to enrich classroom language development, and presents an interesting area for conducting further related research. Girls also identified more strongly with characters and discussed character development at a much higher rate. Although students frequently identified with characters of the same gender, both boys and girls also identified with characters of the opposite gender. Only boys "dis-identified" with a female protagonist saying, "I am not like character X because I am not a girl." Girls did not disidentify with male characters on these grounds. The most significant difference in perspective, and perhaps something specifically for teachers to note, was in the images boys have of boys: While girls' responses indicated they perceived the contradictory nature of boys, boys saw only the positive, phrasing their images of boys, for example, as "strong and independent."

Action research projects of this nature, involving school and university partnerships, have much to offer both curriculum and professional development for teachers and teacher educators. 'Appreciation' of gender diversity is not sufficient - knowledge and understanding must also become embedded in curriculum design and classroom routines and expectations. Peterson (2004) suggests that best practices for teachers that support male and female literacy education demand a commitment to observing noticeable trends in reading and writing of a variety of texts. As previously referenced in Hammett \& Sanford's (2008), work Peterson also considered the goals to be the expansion of our teaching repertoires, rather than prioritizing the learning of one gender over the other.

\section{The Road Ahead: Boys' Literacy Teacher Inquiry Project}

On a larger scale, and supported with funding from the Ontario Ministry of Education (2009), this study was a three-year multi-school initiative that set out to address ways of, bridging the traditional divide between educational theory and professional practice through teacher inquiry. 
From autumn 2005 through summer 2008, one hundred and three teams, involving one hundred forty five schools from English-language boards, were guided by a project team from the Ontario Institute for Studies in Education (OISE) in the Boys' Literacy Achievement Teacher Inquiry Project. A parallel project was undertaken in French-language boards and included forty inquiry teams. Schools were involved in this large-scale collaborative teacher inquiry project designed to address the gender gap in literacy achievement. Elementary and secondary schools that worked with small samples of boys were included, as well as several projects that involved the entire population of boys in the school. Teachers and administrators worked together to examine which strategies mattered most in impacting boys' engagement with and achievement in literacy development.

In summary, findings from the Teacher Inquiry Project note the following teaching practices as clearly assisting in promoting boys' literacy over time:

- Teaching with a wide variety of teaching materials

- Acknowledgement of and emphasis on the very social nature of literacy learning

- Harnessing the power of talk

- The importance of listening to student voices (and recognizing that boys need choices!)

- Utilizing clear assessment practices - these were consistently seen to lead to more precise teaching and effective design of differentiated approaches

- Increasing active learning to enhance motivation, e.g., games and competition

- The use of technology as a valuable teaching and learning tool

- Collaborative teaching - to promote and sustain more positive school climates

Highlights of the participating teachers' learning directly related to boys' literacy attainment highlighted shared reading as a part of classroom instruction and its positive effects on improved engagement and achievement. Student opinion surveys were used throughout the inquiry to gather input about choices materials, and the data gathered helped to shape both teaching and the ongoing selection of reading materials. Furthermore, the use of a wide array of arts - e.g., visual, dramatic, music - encouraged a wide variety of boys' and girls' responses before, during, and after reading. In one school that participated, over $70 \%$ of the cohort group (mostly boys) indicated they preferred this approach.

A complete report of this project was prepared by a research team at the Ontario Institute for Studies in Education and published by the Ontario Ministry of Education in February 2009 (http://www.edu.gov.on.ca/eng). The report contains more details about significant findings, and identifies teaching practices seen to yield the most promising results for boys. By all accounts, to date, the projects have been successful in promoting improvements in boys' interest, engagement and achievement in reading, writing and oral language.

Also in Winter 2009, Me Read? And How! a sequel to the successful Me Read? No Way! (Ontario Ministry of Education, 2004) was published. It draws from the broad range of learning on boys' literacy that emerged from the inquiry teams, and uses quotes and ideas in the inquiry teams' final reports. The booklet promotes user-friendly specific strategies, learned in Ontario schools during the last three years of this project.

\section{Conclusions}

Research shows there are many differing views on the issues of boys' literacy achievements, and available evidence suggests there may be complex and unfortunate outcomes directly related to how schools are currently handling the education of students. Governments, policy makers, 
administrators, teachers and parents all need to examine the available research to inform strategies and interventions that can support boys and girls in their literacy development. Action Research projects, like those described here, can provide teachers, administrators, and teacher educators with opportunities to participate in collaborative research projects that offer valuable insights into effective practices and identify areas in need of further research and development.

Understanding the gendered nature of behavior offers new hope for more effective teaching and learning, but only if we better understand what literacy looks like for boys and how our classroom practices relate to what boys are (or are not) learning. For example, how much do teachers really know about boys' self-image of themselves as writers? (and the sources of/ influences on their development as writers?) Spence (2008) sees teacher education for promoting boys' literacy as including research and practice, opportunities for more explicit modeling of teachers' own reading and writing in classroom practices and while not everyone can be an Eric Walters, how can we (as educators) learn from what he has found works well in classrooms? What are teachers (pre-service and in-service) learning about classroom environments for writing; effective instructional frameworks; authentic pedagogy; and teaching/learning strategies for promoting writing in contemporary classrooms? Booth (2002) suggests we must:

Work against stereotype and move towards archetype. Value and accept boys' responses, and find ways to stretch and deepen them. Help them to find their own emotional selves inside the texts we share, in safe ways, together. Stand for all of the literacies in all the forms and shapes they take, mindful of print's own and particular value. Model what you want them to become - print-strong men who believe in equity. Question and wonder about all the texts you meet, and include boys in the tentative process of meaning making. Let them know that there are different types of literate men and that we value all of them. (p. 101).

Serious consideration must be given to how we might actively promote and further develop 'boyfriendly' environments in classrooms and schools that recognize these differences and support the kinds of climates for learning, where research shows boys respond positively. Smith and Wilhelm (2002) have suggested we look carefully at the "...individual differences, variety, and plurality that make diversity a strength of our classrooms" (p. 184), rather than identifying achievements and needs only through test scores and statistical averages in which those differences quickly become lost. In short, literacy in school needs to be more like literacy in life (Smith \& Wilhelm, 2006).

Much more research needs to be done on school culture (Spence, 2008), and on providing anecdotal data from 'voices' of young men who participate. Spence (2008) suggests whole school approaches to a "gendered lens" is a useful framework for examining teaching and learning of literacy - i.e., all curriculum areas, all grade levels, and across the broader school community. Whole school planning would be the starting point for action research: analysis of school data leading to gap analysis and understanding of differences in performance.

Components of this kind of whole-school planning will involve negotiating priorities, developing an action plan, implementing the plan and locating resources, evaluation and ongoing review. High expectations are seen as meaning more than simply "raising the bar": It also means teachers must be willing to re-group, re-teach, re-visit, to provide support and seriously examine motivations, attitudes, purposes, and strategies for an inclusive writing culture.

Many researchers and educators have already drawn attention to the fact that it is not simply a matter of 'prioritizing' the educational needs of boys over girls or vice versa (FroeseGermain, 2006). Rather, it is critical for teachers to recognize gender differences and know how 
to respond appropriately to inherent diversities. It is also essential to remember that not all boys are failing reading tests, doing less well than girls, or 'hate' to read. As educators, we must avoid the 'one-size fits all' approach to instruction.

Boys' achievement and, increasingly, greater awareness of the complexities related to boys' literacy, is improving. Nevertheless, the problems of gender difference are connected to a range of factors situated in the society in which the boys live, the complex interactions of the variables in their lives, the nature of the individual, the culture of the peer group, the relationship of home and schooling, the philosophy of the school, the availability of resources, the strategies the teacher incorporates in the classroom program, and the changing nature of literacy. The literate lives of students in schools today depend on mandates for authentic, inclusive change. As Laurence Stenhouse once said (Rudduck, 1988), "It is teachers who, in the end, will change the world of school by understanding it." 


\section{References}

Allen, M., \& Vaillancourt, C. (2004). Class of 2000: Profile of postsecondary graduates and student debt. Statistics Canada (81-595-MIE2004016). Retrieved from http://www.statcan.gc.ca/pub/81-595-m/81-595-m2004016-eng.pdf

Arnot, M., Gray, J., James, M. \& Rudduck, J. (1998). Recent research on gender and educational performance, London: Office for Standards in Education.

Booth, D. (2001). Reading and writing in the middle years. Markham, ON: Pembroke.

Booth, D. (2002). Even hockey players read: Boys, literacy and learning. Toronto: Pembroke.

Booth, D. (2006). Reading doesn't matter anymore. Markham, ON: Pembroke.

Booth, D. (2009). Whatever happened to language arts? Toronto: Pembroke.

Booth, D., \& Green, J. (2009). Pilot project research report. Oakville, ON: Rubicon Publishing.

Booth, D., \& Rowsell, J. (2007). The literacy principal: Leading, supporting, and assessing reading and writing initiatives. ( $2^{\text {nd }}$ ed.). Markham, ON: Pembroke.

Brown, L. (2006, June 23). Dropout, failure rates linked to language. Toronto Star, A01. Retrieved from http://proquest.umi.com/pqdweb?did=1065164161\&sid=1\&Fmt=3\&clientId=11263\&RQ $\mathrm{T}=309 \&$ VName $=$ PQD\&cfc $=1$

Collins, C., Kenway, J., \& McLeod, J. (2000). Factors influencing the educational performance of males and females in school and their initial destinations after leaving school. Commonwealth of Australia. DEST(Aus.). Retrieved from http://www.dest.gov.au/sectors/school_education/publications_resources/profiles/factors_ influencing_educational_performance.htm\#publication

Crawford, P. (2009). Inquiry on the internet. In David Booth (Ed.), Whatever happened to language arts, (pp. 117-120). Markham, ON: Pembroke.

Donahue, P., Finnegan, R., Lutkus, A., Allen, N., \& Campbell, J. (2001). The nation's report card: Fourth-grade reading 2000 (NCES 2001-499). Washington, DC: U.S. Government Printing Office. Retrieved from http://nces.ed.gov/pubsearch/pubsinfo.asp?pubid=2001499

Epstein, D., Elwood, J. Hey, V., \& Maw, J. (Eds.). (1998). Failing boys?: Issues in gender and achievement. Buckingham, UK: Open University Press.

Francis, B. \& Skelton, C. (2005). Reassessing gender and achievement. London: Routledge. 
Frank, B., Kehler, M., Lovell, T. \& Davison, K. (2003). A tangle of trouble: boys, masculinity and schooling - future directions, Educational Review, 55(2), 119-133.

Froese-Germain, B. (2006). Educating boys: Tempering rhetoric with research. McGill Journal of Education, 41(2), 145-154.

Hammett, R.F. \& Sanford, K. (Eds.). (2008). Boys and girls and the myths of literacies and learning. Toronto: Canadian Scholars' Press.

Leheman, B. (2009). Children's literature in a testing time. Language Arts, 86 (3), 196-200.

Lingard, B., Martino, W., Mills, M., \& Bahr, M. (2002). Addressing the educational needs of boys. Canberra: Department of Education, Science and Training. Retrieved on June 18, 2007, from

http://www.dest.gov.au/sectors/school_education/publications_resources/profiles/address ing_educational_needs_of_boys.htm

Marshall, L. (2009). Going graphic in reading and writing. In David Booth (Ed.), Whatever happened to language arts, (pp. 44- 49). Markham, ON: Pembroke.

Martino, W. (2008). Boys underachievement: Which boys are we talking about? [Research Monograph \# 12]. What Works? Research into Practice. Toronto: Ontario Ministry of Education.

Martino W. \& Kehler, M. (2007). Gender-based literacy reform: A question of challenging or recuperating gender binaries. Canadian Journal of Education, 30(2), 406-431.

Martino, W., \& Pallotta-Chiarolli, M. (2003). So what's a boy? Addressing issues of masculinity and schooling. Buckingham: Open University Press.

Newkirk, T. (2000). Misreading masculinity: Speculations on the great gender gap in writing. Language Arts, 77, 294-300.

Ontario Ministry of Education (2009). The road ahead: Boys' literacy achievement teacher inquiry project 2005-2008. Toronto: Queen's Printer.

Ontario Ministry of Education (2004). Me read? No way! A practical guide to improving boys' literacy skills Toronto: Queens Printer.

Peterson, S. (2004). Supporting boys' and girls' literacy learning. Orbit, 34(1), 33-37.

Rakuc, K. (2008). The boys' club. In David Booth (Ed.), It's critical: Classroom strategies for promoting critical and creative comprehension, (pp. 61-64). Markham, ON: Pembroke.

Roos, D. (2008). How net generation students learn and work. Howstuffworks, May 5, 2008, http://communication.howstuffworks.com/how-net-generation-students-work1.htm 
Rowe, K. \& Rowe, K. (2006). BIG issues in boys' education: Auditory processing capacity, literacy and behaviour. Background paper to keynote address presented at the Second International Conference on Boys in Education, Massy University. Auckland, NZ, April 19-21, 2006.

Rudduck, J. (1988). Changing the world of the classroom by understanding it: A review of some aspects of the work of Lawrence Stenhouse. Journal of Curriculum and Supervision, 4(1), 30-42.

Rutter, M., Caspi, A., Fergusson, D., Horwood, L. J., Goodman, R. Maughan, B., Moffitt, T.E., Meltzer, H., \& Carroll, J. (2004). Sex differences in developmental reading disability New findings from 4 epidemiological studies. JAMA, 291(16), April 28, 2004, 20072012.

Smith, M., \& Wilhelm, J. (2002). "Reading don't fix no Chevys": Literacy in the lives of young men. Portsmouth, NH: Heinemann.

Smith, M. W., \& Wilhelm, J. D. (2006). Going with the flow - How to engage boys (and girls) in their literacy learning. Portsmouth, NH: Heinemann.

Spence, C. M. (2008). The joys of teaching boys. Markham: Pembroke Publishers. Retrieved from: http://www.stenhouse.com/assets/pdfs/8230fm.pdf

Sternberg, R. J., \& Preiss, D. (Eds.). (2005) Intelligence and technology, Florence, Ky: Routledge.

Tapscott, D. (2009). Grown up digital. New York: McGraw-Hill.

Taylor, D. L. (2004). "Not just boring stories": Reconsidering the gender gap for boys. Journal of Adolescent \& Adult Literacy. Dec 2004/Jan 2005, Vol. 48, No. 4, 290-298. Retrieved from: http://www.accessmylibrary.com/coms2/summary_0286-11881334_ITM

Younger, M., \& Warrington, M. (2005a). Raising boys' achievement. Research Report RR636, DFES and University of Cambridge, Faculty of Education. Retrieved from: http://www.dcsf.gov.uk/research/data/uploadfiles/RR636.pdf

Younger, M., \& Warrington, M., with McLellan, R. (2005b). Raising boys' achievements in secondary school: Issues, dilemmas and opportunities. Maidenhead: Open University Press. 


\section{APPENDIX A}

\section{A LIST OF ADDITIONAL READINGS \& RELATED RESOURCES}

Abraham, J.A. (2008). Back to the future on gender and anti-school boys: a response to Jeffrey Smith. Gender and Education, 20(1), January 2008, 89-94.

Alloway, N., Freebody, P., Gilbert, P. \& Muspratt, S. (2002). Boys, literacy and schooling: Expanding the repertoires of practice. Nathan, Australia: Commonwealth Department of Education Science \& Training. Retrieved from http://www.dest.gov.au/NR/rdonlyres/835D5DAC-D69C-4716-91EECB6E2DCDA934/1564/BoysLiteracy.pdf

Applebee, A. N. \& Langer, J. A. (2006). The state of writing instruction in America's schools: What existing data tell us. Center on English Learning \& Achievement, University at Albany, State University of New York. Retrieved from http://www.albany.edu/aire/news/State\%20of\%20Writing\%20Instruction.pdf

Baer, J., Baldi, S., Ayotte, K. \& Green, Patricia J. (2007). The reading literacy of U.S. fourthgrades students in an international context results from the 2001 and 2006 progress in international reading literacy study (PIRLS). U.S. Department of Education, Institute of Education Sciences. Retrieved from http://nces.ed.gov/pubsearch/pubsinfo.asp?pubid=2008017

Barrs, M. (1998). Texts and subtexts in boys and reading. London: Centre for Language in Primary Education.

Barrs, M. \& Pidgeon, S. (Eds.). (1993). Reading the difference: Gender and reading in the primary school. London: Centre for Language in Primary Education/London Borough of Southwark.

Barrs, M. \& Pidgeon, S. (Eds.). (2002). Boys and writing, London: Centre for Literacy in Primary Education.

Beach, R. \& Myers, J. (2001). Inquiry-based English instruction: Engaging students in life and literature. New York: Teachers College Press.

Bearne, E. (2004). Raising boys' achievements in literacy. Manuscript in preparation. September 2004. Retrieved from http://www-rba.educ.cam.ac.uk/Paper\%20EB.pdf

Beers, K. G. (1996). No time, no interest, no way! The 3 voices of aliteracy. School Library Journal, March 1996. 
Blair, H. \& Sanford, K. (2004). Morphing literacy: Boys reshaping their literacy practices. University of Alberta. Retrieved from http://www.onlineopinion.com.au/documents/articles/morphing_literacy.pdf

Bodkin, B. (2004). Responding to the complexity of boys' learning: Promising practices from school districts. Orbit, 34(1). Retrieved from http://www.oise.utoronto.ca/documents/barbara.pdf

Burgess, S., McConnell, B., Propper C., \& Wilson, D. (2003). Girls rock, boys roll: An analysis of the age 14-16 gender gap in English schools. CMPO Working Paper Series No 03/084. Bristol: University of Bristol, CMPO. Retrieved from www.bris.ac.uk

Brozo, W.G. (2002). To be a boy, to be a reader. Newark, DE: International Reading Association.

Canadian Council on Learning. (2007). State of learning in Canada-No time for complacency. Report on Learning in Canada 2007. Ottawa. Retrieved from http://www.cclcca.ca/NR/rdonlyres/5ECAA2E9-D5E4-43B9-94E484D6D31BC5BC/0/NewSOLR_Report.pdf

Cherland, Meredith (2008). Harry's girls: Harry Potter and the discourse of gender. Journal of Adolescent \& Adult Literacy, 52(4), 273-282.

Clay, Victoria (2003). Why take a different approach to literacy just for boys? Boys in School program, Family Action Centre, University of Newcastle. Retrieved from: http://www.newcastle.edu.au/centre/fac/binsp/downloads/boys_literacy.pdf

Coles, M., \& Hall, C. (2001). Boys, books and breaking boundaries: Developing literacy in and out of school. In W. Martino and B. Meyenn (Eds.), What about the boys? Issues of masculinity in schools (pp. 211-221). Buckingham, UK: Open University Press.

Coley, R. (2001). Differences in the gender gap: Comparisons across racial/ethnic groups in education and work. Princeton: Educational Testing Service, Policy Information Center. Retrieved from http://www.ets.org/research/pic

Condie, R. (2006). Review of strategies to address gender inequalities in Scottish schools. Scottish Executive Social Research. Retrieved from http://www.scotland.gov.uk/Resource/Doc/113793/0027652.pdf

Croxford, L., Tinklin, T., Ducklin, A., \& Frame, B. (2001). Gender and pupil performance in Scotland's schools. Centre for Educational Sociology, Edinburgh University. Retrieved from http://www.ces.ed.ac.uk/PDF\%20Files/Gender_Report.pdf

DCSF (2007). Gender and education: the evidence on pupils in England. Retrieved from www.standards.dfes.gov.uk/genderandachievement/goodpractice/ 
DEST (2006). Motivation and engagement of boys: Evidence-based teaching practices.

Australian Government. Retrieved from

http://www.dest.gov.au/sectors/research_sector/publications_resources/profiles/motivatio n_engagement_boys.htm

DfEE (2001). Schools building on success - Raising standards, promoting diversity, achieving results. CM 5050. Retrieved from http://www.archive.officialdocuments.co.uk/document/cm50/5050/5050.htm

Daly, C. (2002). Literature search on improving boys' writing. London: Ofsted. Retrieved from www.basic-skills-observatory.co.uk

Donahue, P. L., Voelkl, K. E., Campbell, J. R. and Mazzeo, J. (1999). NAEP 1998 Reading report card for the nation and the states. Education Statistics Quarterly 1(2). July 1999. Retrieved from: http://nces.ed.gov/programs/quarterly/Vol_1/1_2/3-esq12-a.asp

Estyn (2008). Closing the gap between boys' and girls' attainment in schools. Her Majesty's Inspectorate for Education and Training in Wales. March 2008. Retrieved from http://www.estyn.gov.uk/publications/Gender_Gap_Report_March_2008.pdf

Frater, G. (1997). Improving boys' literacy: a survey of effective practice in secondary schools. London: Basic Skills Agency,

Frater, G. (2000). Securing boys' literacy: a survey of effective practice in primary schools. London: Basic Skills Agency.

Gee, J. P. (2003). What video games have to teach us about learning and literacy. New York: Palgrave Macmillan.

Gillborn, D. \& Mirza, H.S. (2000). Education inequality: Mapping race, class and gender: A synthesis of research evidence. London: Ofsted. Retrieved from http://www.ofsted.gov.uk/Ofsted-home/Publications-and-research/Browse-allby/Education/Inclusion/Minority-ethnic-children/Educational-inequality-mapping-raceclass-and-gender/(language)/eng-GB

Goodson, I, Knobel, M., Lankshear, C., \& Mangan, M. (2002). Cyber spaces/Social spaces: culture clash in computerized classrooms. New York: Palgrave Macmillan.

Government of Ontario (2006). McGuinty government helps close gender gap in reading and writing. Backgrounder, January 19, 2005. Toronto: Queen's Printer for Ontario. Retrieved from http://www.premier.gov.on.ca/news/Product.asp?ProductID=205

Gurian, M. (1998). A fine young man: What parents, mentors and educators can do to shape adolescent boys into exceptional men. New York: J.P. Tarcher.

Healey, J. (Ed.). (2005). Masculinity: Men and boys. Thirroul, NSW, Australia: Spinney Press. 
Hicks, C. \& Andrego, S. (2007). Boys and Literacy. Boys reading website. Colorsports Publishing. Retrieved from http://www.boysrreading.com/boys_and_literacy.php

Hillocks, G. (1999). Ways of thinking, ways of teaching. New York: Teachers College Press.

Jenkinson, D. (1998). Profile: Eric Walters. Canadian Review of Materials. Interview conducted in Mississauga, ON, on Sept. 26, 1998. Retrieved from http://www.umanitoba.ca/cm/profiles/walters.html (See also: www.ericwalters.net/)

Kavanagh, J. (2007). Literacy gap between boys \& girls. Boy-friendly educational approaches for disinterested male students. Boys' Education Website. Apr 12, 2007. Retrieved from http://boyseducation.blogspot.com/2008/02/literacy-gap-between-boys-girls-boy.html

Kindlon, D., \& Thompson, M. (1999). Raising Cain: Protecting the emotional life of boys. New York: Ballantine.

King, J. E. (2006). Gender equity in higher education. American Council on Education, Center for Policy Analysis.

Lee, J., Grigg, W. S., \& Donahue, P. L. (2007) The nation's report card: reading 2007. U.S. Department of Education, Institute of Education Sciences. September 2007. Retrieved from http://nces.ed.gov/nationsreportcard/pubs/main2007/2007496.asp\#pdflist

Macdonald, B. (2005). Excerpts from boy smarts - Mentoring boys for success at school. Mentoring Boys Website. Retrieved from http://www.mentoringboys.com/literacy.html

Manguel, A. (1996). A history of reading. New York: Viking Press.

Marsh, J., \& Millard, E. (2000). Literacy and popular culture: Using children's culture in the classroom. London: Paul Chapman/Sage.

Martino, W. (2003). Boys, masculinities, and literacy: Addressing the issues. Australian Journal of Language and Literacy, 26(3), 9-27.

Martino, W. and Kehler, M. (2006). Male teachers and the 'boy' problem: An issue of recuperative masculinity politics. McGill Journal of Education, 41(2), 113-131.

Matthews, B. (2005). Engaging education: Developing emotional literacy, equity and coeducation. Buckingham: McGraw-Hill/Open University Press.

Meiers, M., Khoo, S.T., Rowe, K., Stephanou, A., Anderson, P., \& Nolan K. (2006). Growth in literacy and numeracy in the first three years of school. ACER Research [Monograph No. 61]. ED496525. ACER Press (Australian Council for Educational Research). June 2006. Retrieved from http://www.acer.edu.au 
Miles, C. \& Richmond, H. (2002). Boys' and girls' literacy: Closing the gap. Roundtable discussion presented at the Literacy Conference, University of British Columbia, July 810, 2002. Retrieved from http://www.pkp.ubc.ca/ocs/literacyproceedings/paper.php?pid=13

Moss, G. (2000). Raising boys' attainment in literacy: Some principles for intervention. Reading, 34(3), 101-106.

Myhill, D. (2002). Boy zones and girl power: Patterns of interaction and response in whole class teaching. British Educational Research Journal, 28(3).

NIA (2001). 2001 A-level and GCSE Results. Briefing note on the 2001 A-level and GSCE examination results in Northern Ireland and the causes of the "gender gap". Briefing Note. Research and Library Service, Research Paper 05/01, 22 August 2001. Retrieved from http://www.niassembly.gov.uk/io/research/0501.pdf

Newkirk, T. (2002). Misreading masculinity: Boys, literacy, and popular culture. Portsmouth, NH: Heinemann.

Newkirk, T. (2003). The quiet crisis in boys' literacy. Education Week [Washington], vol.23, no.2, 34, September 10, 2003.

Newkirk, T. (2006). Media and literacy. Educational Leadership, September 2006, 62-66.

Ofsted/EOC (1996). The gender divide. London: HMSO

Ofsted (2002). The national literacy strategy: the first four years 1998-2002. DFES Website. Retrieved from http://www.standards.dfes.gov.uk/primary/publications/literacy/63649/hmi555_nls_first4 years.pdf

Ofsted (2003a). Yes he can: Schools where boys write well. July 2003. HMI 505. Retrieved from http://www.standards.dfes.gov.uk/primary/publications/literacy/765289/hmi505_nls_boy swritewell.pdf

Ofsted (2003b). Boys' achievement in secondary schools. July 2003. HMI: 1659. Ofsted Publications Centre. Retrieved from http://www.ofsted.gov.uk/Ofsted-home/Publicationsand-research/Browse-all-by/Education/Pupils/Boys-achievement-in-secondaryschools/(language)/eng-GB

Office of the Premier (2005a). McGuinty government helps close gender gap in reading and writing. Backgrounder, January 19, 2005. Retrieved from http://www.premier.gov.on.ca/news/Product.asp?ProductID=205 
Office of the Premier (2005b). Premier congratulates students on higher literacy test scores.

Backgrounder, May 5, 2005. Retrieved from

http://www.premier.gov.on.ca/news/Product.asp?ProductID=127

Office of the Premier (2005c). McGuinty government helps improve student literacy and numeracy skills. Backgrounder, May 5, 2005. Retrieved from

http://www.premier.gov.on.ca/news/Product.asp?ProductID=128

Office of the Premier (2005d). Closing the Reading Gap. Backgrounder, January 19, 2005.

Retrieved from http://www.premier.gov.on.ca/news/Product.asp?ProductID=204

Organization for Economic Co-operation and Development. (2004). Messages from PISA 2000. Paris: OECD Publications.

O'Sullivan, C.Y., Lauko, M.A., Grigg, W.S., Qian J. \& Zhang, J. (2003). The nation's report card: Science 2000. Education Statistics Quarterly, 5(1), 43-47. Retrieved from http://nces.ed.gov/programs/quarterly/vol_5/5_1/q4_1.asp

O’Sullivan, Brown and Jones (2004). Effective teaching to raise boys' literacy learning and achievement. Centre for Literacy in Primary Education. Retrieved from:

http://www.standards.dfes.gov.uk/ntrp/lib/pdf/OSullivan.pdf

Pirie, B. (2002). Teenage boys and high school English. Portsmouth, NH: Heinemann.

PNS/UKLA (2004). Raising boys' achievements in writing. Joint Research Project, United Kingdom Literacy Association, Supported by Primary National Strategy, October 2004, Royston, UK: UKLA. Retrieved from http://www.standards.dfes.gov.uk/primary/publications/literacy/1094843/pns_ukla_boys0 94304report.pdf

Pollack, W. (1998). Real boys: Rescuing our sons from the myths of boyhood. New York: Random House.

Prensky, M. (2001). Digital game-based learning New York: McGraw-Hill.

Raymond, M. (2008). High school dropouts returning to school. Culture, Tourism and the Centre for Education Statistics, Statistics Canada. (81-595-M-No. 055) Ottawa: Minister of Industry. Retrieved from http://www.statcan.gc.ca/pub/81-595-m/81-595-m2008055eng.pdf

Rossi, R. (2006). Where the boys aren't. Chicago Sun Times. May 3, 2006, 16-17.

Rowan, E., Knobel, M., Bigum, C., \& Lankshear, C. (2002). Boys, literacies and schooling: The dangerous territories of gender-based literacy reform. Buckingham, UK: Open University Press. 
Rushkoff, D. (1997). Children of chaos, surviving the end of the world as we know it. London: HarperCollins.

Safford, K., O’Sullivan, O. \& Barrs, M. (2004). Boys on the margin: promoting boys' literacy and learning at key stage 2, London: Centre for Literacy in Primary Education.

Salahu-Din, D., Persky, H., \& Miller, J. (2008). The nation's report card: Writing 2007. (NCES 2008468). U.S. Department of Education, Institute of Education Sciences. Retrieved from: http://nces.ed.gov/pubsearch/pubsinfo.asp?pubid=2008468

Sanford, K. (2002). Popular media and school literacies: Adolescent expressions. In R. Hammett, and B. Barrell Digital expressions: Media literacy and English language arts (pp. 21-48). Calgary, AB: Detselig Enterprises Ltd.

Sanford, K. \& Blair, H. (2002a). Morphing literacy: Boys reshaping their literacy practices. University of Alberta. Retrieved from http://www.onlineopinion.com.au/documents/articles/morphing_literacy.pdf

Sanford, K. \& Blair, H. (2002b). Engendering public education: Single sex schooling in Western Canada. In A. Datnow and L. Hubbard (Eds.), Gender in policy and practice:

Perspectives on single sex and coeducational schooling (pp. 90-108). Routledge Falmer Press. Retrieved from http://www.education.ualberta.ca/boysandliteracy/singlesex.htm

Sax, L. (2005). Why gender matters: Why parents and teachers need to know about the emerging science of sex differences. New York, NY: Doubleday.

Schmidt, S. (2006). Boys exhibit high literacy skills with video games. UBC Website. May 31, 2006. Retrieved from http://www.canada.com/vancouversun/news/story.html?id=d91eb782-4169-4a6b-ad09$1868 \mathrm{~d} 2 \mathrm{a} 2783 \mathrm{~b}$

(See also www.jsworldwide.com/guys_read.html or http://www.guysread.com/)

Smagorinsky (2002a). Acquiescence, accommodation, and resistance in learning to teach within a prescribed curriculum. English Education, April 2002, 34(3) 187-213.

Smagorinksy (2002b). Teaching english through principled practice. Upper Saddle River, NH: Merrill/Prentice Hall.

Spence, C.M. (2008). The joys of teaching boys. Markham: Pembroke Publishers. Retrieved from http://www.stenhouse.com/assets/pdfs/8230fm.pdf

Sternberg, R. J. and Preiss, D. (Eds.). (2005). Intelligence and technology, Florence, Ky: Routledge.

Street, B. (Ed.). (1993) Cross-cultural approaches to literacy. Cambridge: Cambridge University Press. 
Turkle, S. (1997). Life on the screen, identity in the age of the internet, New York: Simon \& Schuster.

Trent, F. \& Slade, M. (2008). Declining rates of achievement and retention: the perceptions of adolescent males. Department of Education, Science and Training (AUS). Retrieved from http://www.dest.gov.au/archive/highered/eippubs/eip01_6/default.htm

Younger, M. (2007). The gender agenda in secondary ITET in England: forgotten, misconceived or what? Gender and Education, 19(3) May 2007, 387-414. Retrieved from http://www.ingentaconnect.com/content/routledg/cgee/2007/00000019/00000003/art0000 7

Younger, M. \& Warrington, M. (2002). Single-sex teaching in a co-educational comprehensive school in England: An evaluation based upon students' performance and classroom interactions. British Educational Research Journal, 28, 353-374

Veen, W. (2003). A new force for change: Homo zappiens. The Learning Citizen, 7, 5-7.

Waters, J. (2005). Book Review: Guys Write for Guys Read. New York, NY: Viking. In Jon Scieszka (Ed.). CM Magazin, September 2, 2005, 12(1). Retrieved from http://umanitoba.ca/outreach/cm/vol12/no1/guyswriteforguysread.html

Worthy, J., Moorman, M., \& Turner, M. (1999). What Johnny likes to read is hard to find in school. Reading Research Quarterly, 34, 12-27.

Worthy, J., Turner, M., \& Moorman, M. (1998). The precarious place of self-selected reading. Language Arts, 75, 296-304.

Zambo, D., \& Brozo, W.G. (2009). Nurturing young male readers. In bright beginnings for boys. Newark, DE: International Reading Association. 